\title{
TO MEASURE IS TO KNOW: THE QUANTIFICATION OF REGULATION
}

\author{
"There is nothing more deceptive than an obvious fact." - Arthur Conan Doyle, \\ The Boscombe Valley Mystery
}

Wim Voermans*

\begin{abstract}
In recent debates and policies on regulation the quantification of effects - in terms of numbers, figures and costs - plays an ever more important role. Whatever the underlying cause for this quantification trend may be, it does allow countries to share information on (the effects of) regulation in ways that were unfathomable before. This paper looks into this regulatory quantification trend and assesses it. The paper discusses the way in which jurisdictions all around the world, perhaps triggered by regulatory competition, are adopting each other's regulatory appraisal practices at an extraordinary pace, in most cases in order to enable policy makers to gather more and better information about the possible effects of regulation. In this process - particularly in OECD countries - these jurisdictions don't just copy each other's quantification methods but to a certain extent also each other's institutional arrangements. One of these effects in any case is that regulators will be able to take decisions on the basis of better information and be more able to weigh up the content of alternative solutions. It can make the regulatory process better informed and more inclusive as well. There are serious downsides to quantification as well, as the conclusion of the paper argues: quantification may make the regulatory more exclusive as well, make the debate during the regulatory process to one sided. It may be abused to fence off an open debate on alternatives, and it does not help to dampen the ambitions of regulators in thinking that every problem can be solved by regulatory intervention; it rather more seems to feed this ambition.
\end{abstract}

\section{Keywords:}

Better regulation, regulation, impact assessment, administrative burden, deregulation, better regulation policy, quantification, appraisal methods, red tape, standard cost model, ex ante evaluation

Wim Voermans is Professor of constitutional law at Leiden University and President of the International Association of Legislation. The current contribution is based on: W. Voermans, 'Meten is weten: de meetbaarheid van regelgeving' in: J. Ten Hoopen, e.a. (eds.) Merkbaar minder regeldruk (Actal, Den Haag 2013) 104, 120. The research this contribution reports on was concluded on 1 May 2014. This research is the yield of the research programme: 'Legitimacy and effectiveness of law and governance in multilevel jurisdictions' of the Leiden Institute of Public Law. 


\section{A. FIGURES, NUMBERS AND WEIGHTS FOR REGULATION}

Remarkable. When we talk about regulation, in recent years we have increasingly done so in terms of figures, weights and numbers. For instance, we know that mid-2012 in the Netherlands there were 1883 parliamentary acts, 2307 governmental decrees ${ }^{1}$ and 5378 ministerial regulations in force. This may be an increase of 242 acts compared to 2004 , but the number of governmental decrees and ministerial regulations has decreased by 94 and 1640 respectively. $^{2}$

\footnotetext{
${ }^{1}$ In the Netherlands called 'Algemene Maatregelen van Bestuur' (amvb for short).

${ }^{2}$ For some time, the suspicion existed that the reduction in the number of regulations had to do with many cosmetic operations, like merely changing the name of the instrument, consolidating a number of acts into one, making omnibus laws. It was suspected that repealed parliamentary acts (statutes) sometimes reemerged formally in the form of statutory instruments, like governmental decrees, or in regulations that - on the grounds of requirements of shared administration - were adopted by provinces or local councils. The suspicion also existed or exists that provisions in repealed public law regulations reappear in the form of provisions in policy regulations (the deregulated working conditions legislation partly returned as policy rules applied by the Dutch Labor Inspection) or in self-regulation. To what extent this happens and the frequency of it has not yet been the subject of any broad study. Tim Borman in RegelMaat has however discussed the phenomenon of combining implementing rules from several laws in one implementation governmental decree. This method ensures that fewer regulations then have to be added. One does wonder who benefits from this. Certainly the actual user of the regulations does not always find this useful. See T.C. Borman, 'Alles ineen: het combineren van uitvoeringsregels' (All in one; combining implementing acts) (2010) RegelMaat (Dutch Journal for Legislative Studies) $275-284$.
} 


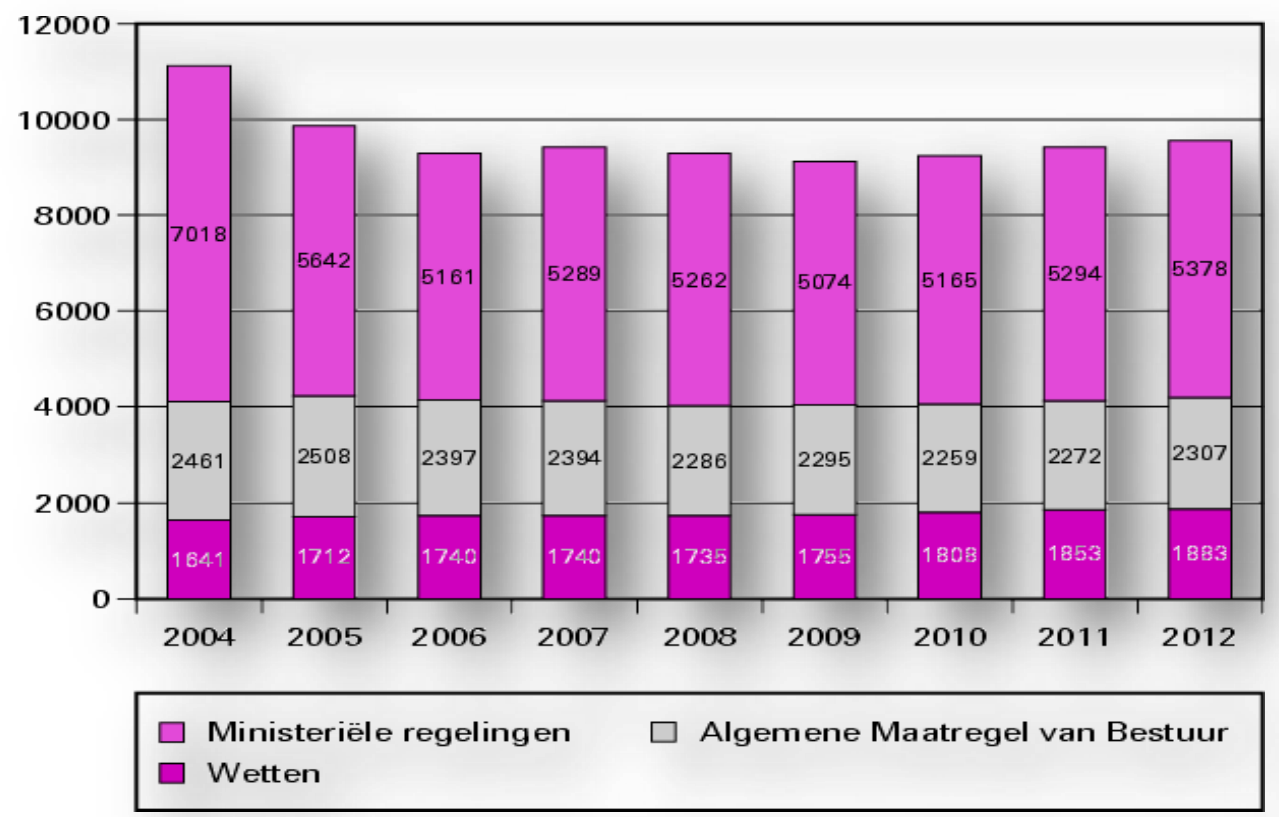

Figure 1: Number of applicable acts, governmental decrees and ministerial regulations as of 1 January 2004 - 2012 as recorded in the Dutch Basiswettenbestand (database containing laws in the Netherlands). ${ }^{3}$

This focus on numbers and figures is by no means just a Dutch phenomenon. In the past few years, the production of legislation in many other European countries has been monitored closely. ${ }^{4}$ For a few years now the Netherlands even has a 'regulation monitor' to keep a tally of the number of regulatory acts in force. ${ }^{5}$ At the level of the Euro-

\footnotetext{
${ }^{3}$ Source Annual Report and final Act Ministry of Security and Justice 2011, Kamerstukken II (Dutch Parliamentary Papers) 2010/11, 33240 VI. This report gives the most detailed account thus far. The Annual Report for 2012 shows a slight increase in the total number of acts, decrees and regulations. The numbers went up from a total of 9,505 on 1 January 2012 to 9,588 on 1 January 2013. See the Annual Report and final Act Ministry of Security and Justice 2012, Parliamentary Papers 2012/13, 33240 VI, chapter 4. This upward trend does however not seem to be persistent. By the end of 2013 the number had dropped to 9,502 acts, decrees and regulations in total. See the letter of the Minister of Security and Justice to the Dutch Senate of 4 December 2013, Parliamentary Papers 2013/14, 31 731, nr. E. Although the Dutch cabinet was somewhat self-congratulatory about these numbers at the level of the central government, the Dutch General Press Agency ANP and Sargasso.nl calculated that actually by April 2014 there had been a total increase of $32 \%$ of national laws, government decrees, regulations of ministers, provinces, municipalities and waterboards nationwide as compared to the level of 2010. In sum some 63.000 laws, decrees and regulations were counted in 2013. The increase is attributed to the large decentralization process set in motion by the Rutte-II cabinet. http://www.ad.nl/ad/nl/1012/Nederland/article/detail/3431602/2013/04/25/Meer-regels-onderRutte.dhtml

${ }^{4}$ See among others W. Voermans, H.M. ten Napel (eds.), Legislative processes in transition (WODC Leiden/Den Haag 2012) and P.O. de Jong \& S.E. Zijlstra, Wikken, wegen en (toch) wetgeven (Weigh, balance and regulate (anyway)) (WODC, Boom juridische uitgevers 2009).

${ }^{5}$ Each year within the framework of the Justice budget a report is made of the results. See among others the Letter of the Minister of Justice with a summary of the number of regulations
} 
pean Union, the number of regulatory acts is also carefully calculated. ${ }^{6}$ Numbers of course don't really say very much, though we cannot deny that numbers, correct or otherwise, often start to lead a life of their own. ${ }^{7}$ For example, participants in the public debate often point to the alleged red tape madness of the EU. Proof of this compulsion to regulate everything comes from 'memes' ${ }^{8}$ like for instance 'without doubt $60 \%$ of our regulatory acts originate from the European Union. ${ }^{9}$ Even though this proportion does not tally with the figures ${ }^{10}$ it is seldom challenged in debates, and it actually plays a role in politics and policies. This is quite a recent development. In the debate on how governments intervene in society and markets - increasingly with regulatory acts numbers and figures are playing an ever more important role. Nowadays many countries make use of so-called 'impact assessments' (ex ante evaluations) when preparing regulatory acts, in which - using more or less objective calculation methods - an estimation is made of the costs or other consequences of a proposed regulation. These ex ante checks as such are not new, but what is new is the (tendency towards) refinement and further objectification of the calculation methods and the quantification of the results.

In this contribution, I will consider the quantification trend in the debate on regulation and regulation policy throughout the past fifteen years. I will highlight three elements in particular. Firstly, the methods which have been deployed over the past years to control

in force as of 1 January 2010 - attached to the 'Adoption of the budget of the Ministry of Justice (VI) for the year 2010', Kamerstukken II (Dutch Parliamentary Papers) 2009/10, 32123 VI.

${ }^{6}$ We know that there are 34,132 EU decisions in force, that account for around 80,000 pages of text. These include 8,937 EU regulations, 1,953 EU directives, 15,561 orders, 4,733 international treaties (including EU treaties) and 2,948 resolutions. See $<$ http://en.euabc.com/word/2152?print=1> accessed 3 January 2013. The total doesn't say very much, though it is interesting to look at the development of EU regulations. The numbers in the EU are decreasing as well. See G.J. Brandsma, 'Europese regelzucht bestaat gewoon niet' (de Volkskrant (online))

<http://www.volkskrant.nl/vk/nl/3184/opinie/article/detail/3304381/2012/08/22/Europeseregelzucht-bestaat-gewoon-niet.dhtml> accessed 22 August 2012.

${ }^{7}$ See W. Voermans, 'Beelden doen er toe' (Images do Matter), in: H. Schouten (eds.), Wetgever en constitutie (Legislature and Constitution); preadviezen en verslag van het symposium gehouden op 23 april 2009 ter gelegenheid van de algemene ledenvergadering van de Vereniging voor wetgeving en wetgevingsbeleid (Wolf Legal Publishers, Nijmegen 2009) 139, 141.

${ }^{8} \mathrm{An}$ image or idea that is usually accepted quickly and unquestioned by many people.

${ }^{9}$ Statement in 2006 made by the then State Secretary for European Matters Nicolaï. See M.A.P. Bovens and K. Yesilkagit, 'De invloed van Europese richtlijnen op de Nederlandse wetgever' (The impact of EU Directives on the Dutch Legislature) Nederlands Juristenblad (Dutch Lawyers Journal) 11 March 2005, 520-528.

${ }^{10}$ Research by De Jong and Herwijer shows that around $12.5 \%$ of Dutch legislation flows from converted EU directives, Alle regels tellen (All rules do count), Beleidswetenschap (Public Administration) 18 (3): 223-241. Bovens and Yesilkagit give a slightly higher percentage: $16.5 \%$ of Dutch legislation is the result of EU directives if you count everything. To know the actual proportion of regulations in force here with a Dutch or EU origin, we would have to include the EU regulations, some orders, international treaties and decisions taken by the EU and perhaps even the case law of the Court of Justice (around 12,000 relevant judgments - though not all count as a 'regulation'). Even then we still probably don't arrive at more than a $20 \%$ share of European law in Dutch law. But, once again, that number says little about the actual 'impact' of EU regulations, nor the influence, value and weight of the regulations that originate nationally. 
(particularly in the Netherlands) the volume of regulatory acts; secondly, the ways in which possible consequences and benefits of regulation can be measured; and thirdly, the significance of the quantification trend for the way in which we deal with regulation.

\section{B. WHY (SO MANY) REGULATORY ACTS?}

There was a time when societies were proud of their many regulations. These regulations, whether written down or not, were viewed as a sign of civilization - one of the reasons to record them for posterity as was done in Roman law in the Justinian Code. Good and acknowledged regulation was also a prerequisite for a flourishing trade sector. According to authors such as Leon Trakman ${ }^{11}$ the Renaissance and the industrial revolution were made possible because of the booming development of the Lex mercatoria (the section of trade law or private law) from the early Middle Ages. Trade in the large commercial centres (the towns) could not rely on a patchwork of differing local legal rules, but needed acknowledged general rules with legal certainty for trustworthy transactions. Italian towns were proud of their large volume of written regulation: they used them as a kind of advertisement. Up till now in our modern societies based on (free or otherwise) market transactions ${ }^{12}$, we have been dependent on clear and acknowledged agreements that are set out in advance in regulatory acts to generate the trust that is necessary for our kind of economic societies. Regulation is a prerequisite for economics and economic growth and because economic growth has become so important, it is also important for our political society. What is special about the history of the past century, is that we don't just recognize the standards written down in legal regulations as a necessary condition for trustworthy transactions within markets, but we increasingly use these regulatory acts to intervene in these markets, and to steer the economic society in this way. Regulation no longer acts merely as a prerequisite but as an independent instrument for government and administration. ${ }^{13}$ This is occurring to the extent that many Western industrialised societies have developed into, what Majone

\footnotetext{
${ }^{11}$ L. E. Trakman, The Law Merchant; The Evolution of Commercial Law (Fred B. Rothman and Co., Littleton Colorado) 11 et seq.

${ }^{12}$ Contrary to self-supporting societies, where life and existence depend on being able to provide the essentials of life by hunting or gathering, or forms of agriculture.

${ }^{13}$ This is actually quite remarkable because rules and regulations are a kind of (authoritative) 'mould' into which we pour agreements. But rules and regulations are often identified with the agreements, or in steering jargon, the 'interventions' themselves. This identification goes so far that in modern social scientific literature 'regulation' is usually seen as any public intervention in markets and societies. See for example R. Baldwin, M. Cave and M. Lodge (eds.), The Oxford Handbook of Regulation (Oxford University Press Oxford 2010) 6 et seq. and B. Morgan $\&$ K. Yeung, An Introduction to Law and Regulation (Cambridge University Press, Cambridge 2007).
} 
refers to as, a 'regulatory state', because of the importance the interventions by regulatory measures play in economic, political and social life. ${ }^{14}$

In the past decade, however, the realization has grown that regulatory acts are not just a blessing for economic growth, but that an incorrect or excessive use of regulation can cause restrictions in economic growth: (outdated) regulation can unnecessarily restrict (new) economic activities; regulation can disrupt spontaneous processes; a pile up of regulation can have undesired knock-on effects (particularly when they are not or insufficiently aligned to each other); regulation can cause such a tremendous administrative burden that economic growth is slowed down. What effects regulation has exactly on economic activities and economic behaviour is a field of investigation in which more detailed research has only been carried out in the past few years. Veljanovski states:

'(...) The economics of regulation (...) is not a settled body of facts but an approach. It uses the economist's toolkit to develop political economy theories of regulation, and assist regulators with the technical details of framing effective regulation. It is however in its formative phases. There remain many puzzles and paradoxes to be explained such as the tremendous growth in regulation in parallel with greater role by markets and economics (...) ${ }^{, 15}$

Even though we don't know exactly what effects (which type of) regulation has on the economy, government policies throughout the world have been trying for the past forty years to somehow stop overregulation. At the base of these policies often lie basic, but no less valid, theoretical concepts, such as the notion that by excessive intervention, by way of regulation, the market freedom of economic actors is reduced to the extent that innovation and competition may be compromised. In economies that are generally free and have an international focus, such as those that developed throughout the world in the 1970s, these are two factors that are essential for growth opportunities in the new global economy. It is therefore not surprising that the roots of most governmental deregulation projects go back to this period. We now live in a world in which countries and trade blocks compete in economic activities, but actually also compete when it comes to regulation. Regulatory competition is not just seen in attempts to create a favourable business or investment climate in a country, but also (like a cast shadow) in the extent to which countries accept each other's solutions and policies on regulation. It is noticeable that many countries that are affiliated with the Organisation for Economic Cooperation and Development (OECD) after 1997 actively adopted each other's 'best practices' in the field of regulation policy. Almost all countries affiliated to the OECD these days have a form of impact assessment for proposed regulatory acts. Practices to safeguard this impact assessment (for example, making it compulsory), and methods to

\footnotetext{
${ }^{14}$ G. Majone, Regulating Europe (Routledge London 1996).

${ }^{15}$ C. Veljanovski, Economic Approaches to Regulation, in: Baldwin, Cave \& Lodge 2010, 34, 35 .
} 
refine it and to (institutionally) incorporate it better in decision-making arrangements are increasingly adopted from each other. ${ }^{16}$

${ }^{16}$ See G. Bounds, Recent Trends in RIA Implementation, paper delivered at the Seminar on Regulatory Impact Assessment (RIA) in the Czech Republic and in other OECD Countries, Prague - 1 June 2012, to be retrieved at: <http://www.oecd.org/gov/regulatorypolicy/50526827.pdf> accessed 15 January 2013. The OECD is very active in this area and supports countries in their regulation policy for example with practical directives. See for example Building an Institutional Framework for Regulatory Impact Analysis (RIA): Guidance for Policy Makers, Paris, OECD 2008. 


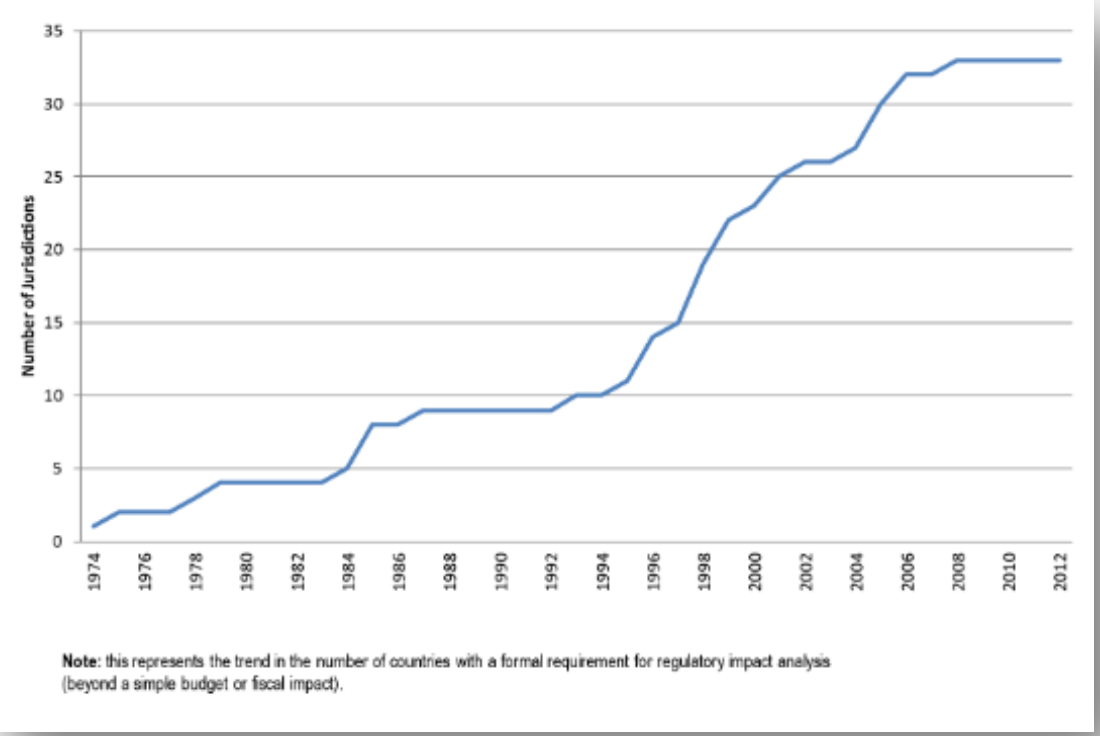

Figure 2: The trend in the number of countries where a regulatory impact analysis is required during the preparation of legislation/regulation. ${ }^{17}$

\section{METHODS TO CONTROL THE VOLUME AND EFFECTS OF REGULA- TION}

\section{The origins of modern regulatory policies}

If we want to understand the current quantification trend an apprehension of its roots can contribute. The history of regulatory policy in the Netherlands offers a good case study since it is more or less representative for similar developments in other industrialized (welfare) states. The Dutch began developing their policy in the 1980's but these policies in turn were inspired by the example of the United States in the early 1970's. Faced with a serious decline in the world and domestic economy the idea caught on in the USA that (excessive) regulation can be an impediment for growth due to the costs involved for businesses as well for the government. In order to prevent regulatory burdens inadvertently harming economic development the US-government chose to develop regulatory policies that would enable better-informed decisions on regulation by securing sound estimates of the costs involved in government regulations This began with President Richard Nixon's "Quality of Life" program, and continued in the 1970s with President Gerald Ford's requirement in Executive Orders 11821 and 11949 for agencies

${ }^{17}$ Source: <http://www.oecd.org/gov/regulatorypolicy/ria.htm> accessed 15 January 2013. 
to prepare inflation/economic impact statements and with President Jimmy Carter's Executive Order 12044 on 'Improving Government Regulations.' These impact statements were overseen by the Office of Management and Budget (OMB) an office within the Executive Office of the President of the United States. In 1980 a dedicated regulatory analysis division was set up (Office of Information and Regulatory Affairs - OIRA) to further and refine the review process. The OMB review process became more formalized in 1981 with President Reagan's Executive Order 12291. Presidents Clinton, Bush and Obama furthered the scope and elaborated the reviewing processes and analyses methods up until the present day. ${ }^{18}$

Although the policies developed in the course of 40 years the basic working hypothesis remained the same: government regulation is more or less perceived and framed as an impediment to market growth, as an activity that is burdensome to citizens and businesses as such, because it either restrains liberties or imposes obligations and - by this very nature - frustrates the growth potential in a free market economy. This in its turn results in a sort of path dependency when analysing regulation. That is predominantly done by looking at the costs and the (mostly) financial burdens government regulation imposes. The methods, processes and tools elaborated over the years have followed suit to the basic idea that regulation frustrates market growth. The same working hypothesis underlies deregulation policies in the US and the Netherlands, we will now discuss. Take away the impediment (regulations) and markets will grow in a more or less linear way - at least that is the theory.

\section{Deregulation in the Netherlands}

The offset for regulatory policies was the worldwide economic crisis of the end of the 1970s. The Dutch economy was hit hard because of its dependency to world markets and serious domestic budget deficits. The example of the US regulatory policies served as a source of inspiration. In the beginning of the 1980 the liberalisation of the markets was seen as the required remedy. Deregulation was one of the methods adopted by many governments worldwide as a way out of the crisis. ${ }^{19}$ In the Netherlands, for example, the first Lubbers cabinet (1982-1986) pursued a rigorous policy to simplify legislation and regulation to help get economic recovery underway. ${ }^{20}$ Later, deregulation

\footnotetext{
${ }^{18}$ Executive Orders 12866, 13422, 12866 and the most recent one Executive Order 13563 'Improving Regulation and Regulatory Review' issued by President Obama on 18 January 2011.

${ }^{19}$ Keynesian economics at the time seemed to have failed and from the middle of the 1970s the monetarism approach advocated by the Chicago School (translated into policy practice by people like Milton Friedman) to economic development became ever more influential. See for a modern day voice of the latter approach and line of reasoning Richard A. Epstein, Curing the Unemployment Blues; Deregulation is our last, best hope, Defining Ideas; A Hoover Institution Journal, November 29 2011. To be retrieved at: <http://www.hoover.org/publications/definingideas/article/101246> accessed 27 March 2014.

${ }^{20}$ The first initiative was taken by the Lubbers cabinet in its Committee to reduce and simplify government regulations, which provided an analysis of the nature and consequences of the phenomenon 'regulation compression'. See final statement of the Geelhoed Committee, $\mathrm{Ka}$ merstukken II 1983/84, 17 931, no. 9.
} 
was applied as a 'tried and tested' recipe. In the period 1994-1998 the 'purple' cabinets (formed by the 'red' - labour - and 'blue' - liberal - political parties) led by Prime Minister Kok - inspired once again by lagging growth - carried out long-term simplification and deregulation programmes in which, besides greater market forces and more competition, deregulation and a better quality of legislation were also pursued. What was remarkable about the Lubbers and Kok deregulation operations was that they were in fact policy projects: one-off operations to reduce the amount of regulation in force. You could, of course, ask the question why ten years after the drastic operation of the Lubbers cabinet, it was once again necessary to cut down on regulation. We now know that this probably has to do with a mechanism that ensures that in our type of society a body of legislation tends to expand automatically. ${ }^{21}$ Regulation leads to more regulation (because of the need to implement them, detail them, coordinate them, update them, etc.) and because we appear to have fallen prey to a kind of 'mechanism syndrome': the idea that there are volume buttons and on and off switches on economic and social processes in society. As a result of the importance that regulation plays in our (market based) societies, we have grossly overestimated the potential of regulation as an instrument to steer our (market based) societies. The fact that regulation is important for economic processes does not mean that the economy allows itself to be steered by regulation. A political reflex from the past decade that is difficult to combat is that when something goes wrong (e.g. market failure ${ }^{22}$ ), we deploy regulation to correct this, ${ }^{23}$ assuming that it costs nothing. ${ }^{24}$

\section{Administrative burden}

By the turn of the century, the focus of government policy in the Netherlands (but also in many other European countries) had shifted somewhat. Governments seemed to realize that project-based deregulation was a fragile method to control regulation because of the ever-increasing supply and also that it made more sense to look more closely at the actual consequences of regulation for the economy. The OECD made the first move by calling for attention to be paid to the consequences regulation can have for economic

\footnotetext{
${ }^{21}$ See W. Voermans, 'The Sisyphus paradox of cutting red tape and managing public risk' (2008) 4(3) Utrecht Law Review 128-144.

${ }^{22}$ In other words, cases in which markets are unable to rectify their own failings independently.

${ }^{23}$ According to Anthony Ogus, for example, we can see 'regulation' as 'the necessary exercise of collective power through government in order to cure 'market failures' to protect the public from such evils as monopoly behaviour, 'destructive' competition, the abuse of private economic power, or the effects of externalities (...). A. Ogus, Regulation: Legal, Form and Economic Theory (Hart Publishing, Oxford 2004).

${ }^{24}$ See Veljanovski 2010, 22-23. Veljanovski points out that in practice market correction by means of regulation is very costly and can itself cause disruptions and inefficiency.
} 
growth. ${ }^{25}$ The organisation called its members to monitor and register costs as a result of regulation. According to the OECD: ${ }^{26}$

'The viability of business activities depends on the market opportunities present, but it is also influenced by legislation, regulations and the administrative requirements governments impose in implementing public policies. The regulatory framework designed by governments is a major factor in the competitiveness of businesses.'

In the Netherlands this call was answered by the 'purple' cabinets which took the first steps in the area of measuring the administrative burden in order to then specifically reduce those costs. ${ }^{27}$ The millennium cabinets Balkenende II to IV (2003-2009) made the reduction of the administrative burden part of its government policy. In particular, at the heart of the policy was the actual reduction of the administrative burden according to objectives laid down in advance. ${ }^{28}$ This was also a response to complaints from the business sector about the high cost caused by the growing administrative requirements in regulation, reporting requirements and the cost as a result of regulation in general. ${ }^{29}$ After the Balkenende II-cabinet, which included the liberal party VVD, set up substantial reduction programmes to try to reduce the administrative burden of regulation by 25 percent (i.e. around $€ 4.1$ billion - to be earned by cutting costs resulting from regulation) one would have imagined a tangible effect. However, after an evaluation in 2006, the Netherlands Court of Audit established that the cabinet had indeed made progress in its objective to reduce - also structurally - bureaucracy and the regulatory burden in the Netherlands (around 20 percent of the goal of 25 percent had been achieved by then), but - and here it comes - the perception of the business sector was that little pro-

\footnotetext{
${ }^{25}$ See for example the report of the Organization for Economic Cooperation and Development, Regulatory reform in the Netherlands. OECD, Paris 1999.

${ }^{26}$ OECD 2007, Cutting Red Tape: Comparing Administrative Burdens across Countries. Paris; OECD 2007. In this latter report, the most recent development in OECD policy is clear: the organization is looking for reliable indicators for the administrative burden. See also paragraph 4 on this.

${ }^{27}$ The so-called MDW programme (Market forces, deregulation and quality of legislation) was successful. The majority of the 70 projects carried out were actually implemented. This resulted in a budgeted $€ 470$ million cost reduction through the simplification of legislation. Kamerstukken II (Dutch Parliamentary Papers), 24 036, no. 284.

${ }^{28}$ The Dutch Balkenende cabinets II to IV fought against the administrative burden not just in the interest of economic growth by paying attention to regulatory burden and costs for businesses, but at the same time they aimed to improve the practicability and quality of legislation (Justice), and to limit the administrative burden for citizens (Ministry of the Interior) and to set up and equip an e-government infrastructure (Ministry of the Interior and Kingdom Relations and Economic Affairs).

${ }^{29}$ The Ministry of Finance estimated the cost of disclosure requirements (for example reports, data etc.) as a result of regulations at around $€ 16.3$ billion. Ministry of Finance, Meer ruimte voor ondernemers door minder lasten; van lastenproductie naar lastenreductie (More room for entrepreneurs by reducing the burden; from burden production to burden reduction), $\mathrm{Ka}$ merstukken II (Dutch Parliamentary Papers), 29 515, 2003/04, no. 1.
} 
gress had been made. ${ }^{30}$ There are various explanations for this paradoxical outcome: certain disclosure requirements, for example, were already no longer observed; businesses had not done away with compulsory administrative processes that were no longer required; and it also takes some time before the situation in practice has adjusted to a new situation. What also played a role, was that many businesses appear to have been given a wake-up call when they became aware of the - now manifest - administrative burden. Partly for this reason, from 2006 onwards the burden reduction policy for the business sector was expanded. Later, the granting and monitoring of licenses and the collection and monitoring of taxes were also included as part of the 'screening' and reduction programmes. The subsequent Balkenende cabinets (2007-2010) and the first Rutte cabinet (2010-2012) also did their best to reduce the administrative burden. In this period, attention was paid in particular to safeguarding a policy that was to lead to a permanent monitor of the administrative burden and to controlling its volume. This will be discussed in more detail in the following paragraph.

4. Safeguards to control the volume of regulation and the administrative burden: IAK and Actal

Until recently, the Netherlands was often referred to as a leading country when it came to policy on the quality and, as a result, the control of its amount of regulation. ${ }^{31}$ Certainly, the Netherlands was one of the first to implement a comprehensive and cohesive policy in the area of safeguarding the quality of legislation. In the policy document Legislation in Perspective 1990, the Netherlands laid the basis for a policy on quality that was imitated in many other countries and even at EU level. In this contribution, I do not want to look at the broad Dutch policy on quality, but just one key part of it: the pursuit of restraint when it comes to regulatory measures. ${ }^{32}$ The essence of this policy that still stands today is:

- no new legislation/regulation before it has been established that no other method (alternatives, self-regulation etc.) can be found as a solution to a problem presented to the government;

- no regulation is considered if it is not certain beforehand that it can be implemented, maintained and is affordable;

- only rules that offer a proportional solution for a problem and that lead to as little burden as possible for citizens, businesses, administrations and institutions are enacted;

- before rules are laid down, a careful appraisal should be made of their necessity

${ }^{30}$ Report by the Netherlands Court of Audit, Reductie administratieve lasten voor het bedrijfsleven (Reduction of administrative burden for businesses), Kamerstukken II (Dutch Parliamentary Papers ) 2005/06, 30 605, nos. 1-2.

${ }^{31}$ See for example the report Regulation - Less is more; Reducing Burdens, Improving Outcomes, of the British Better Regulation Taskforce (BRTF), London March 2005 and OECD 2007.

${ }^{32}$ See for example the key directions 6 and 7 of the Aanwijzingen voor de regelgeving (Dutch Drafting Directives). 
- rules are established at as low a cost and burden as possible and with as great an effect as possible, and this assessment should be checked.

What is immediately noticeable in this twenty-year-old Dutch policy on legislation is that where it is concerned with the control of the volume and the burden of regulation, it mainly focuses on the preparation phase of legislation at departmental level. There is little attention for the phase after the final enactment of regulation. How can we follow whether regulation had the effect that we expected of it in practice? Who keeps a check on the amount of regulation and the burden on balance that this brings over the years? Is there a overseeing eye to monitor regulation, such as in France and the United Kingdom (Law Commission)? This is not to say that there is no attention at all in the Netherlands for this, but the focus is more on the preparatory phase. It is also notable that for the monitoring - the safeguarding of the policy - the Netherlands reverts to a kind of intervention, i.e. a check by other departments in the phase prior to the discussion in the Council of Ministers. Up till 2011, the Netherlands had a muddle of almost a hundred ex ante checks on legislation/regulation in which each time one or more quality dimensions were dealt with. Since 2011 all these checks have been integrated in the Integral Assessment Framework (in Dutch: IAK) in which all interdepartmental quality aspects are incorporated that could play a role in the formation of policy and regulation. This IAK is a protocol that is split into seven clear dimensions ${ }^{33}$ that have to be considered. ${ }^{34}$ An impact assessment of financial, administrative and other burdens (for example environmental effects) of a regulation forms an important part of the IAK check. A final observance: the results of the checks and impact assessment are intended in particular for internal deliberation. In the Netherlands, we do not have the practice that all data that arises from a check, or impact assessment, is made public in a separate document as occurs with impact assessments for proposals for directives or regulations in the European Union. The results of impact assessments in the Netherlands are usually combined and summarized in the explanatory notes of a proposal for a regulation.

\section{Actal}

Each of these IAK dimensions then have to be reported in an assessment file and the protocol also indicates which departments can check these assessment files. The Ministry of Security and Justice plays a role in the review of all dimensions and fulfils a kind of coordinating role. The Dutch system is special because it is an internal system. The assessment files, for example about the impact assessment, are as I said not published with the proposal for the regulation, as is the case in other countries (United Kingdom, but also in the EU itself). There are advantages to such a system. On the basis of the outcome in the assessment file, a different course can be chosen without all too great

\footnotetext{
${ }^{33}$ The following dimensions are considered: 1 . What is the reason?, 2. Who is involved?, 3. What is the problem?, 4. What is the objective?, 5. What justifies government intervention?, 6. What is the best instrument?, 7. What are the consequences?

${ }^{34}$ The IAK was updated and simplified in December 2012 to make it more user-friendly.
} 
political consequences. On the other hand, there is the danger that the butcher is inspecting his own meat, as it were.

To face this problem, since the turn of the century the Netherlands has had an Advisory Board on Administrative Burden (in Dutch: Actal). Actal, a 'temporary' and independent advisory organ, provides advice to the government and the Dutch Parliament on how to keep the regulatory burden for businesses, citizens and professionals in the care, education, security and social security sectors to a minimum. After twelve years of extensions we can conclude that Actal has been given a semi-permanent status. In June 2011 it was announced that Actal will be transformed from a temporary to a permanent advisory board. In anticipation of this, the mandate of Actal has already been adjusted in the 2011 decree establishing the Actal Advisory Board. ${ }^{35}$ Contrary to the period 20002010 the assessment of Actal is not limited to just the administrative burden, but is extended to include the regulatory burden ${ }^{36}$ and it can provide advice upon request. An independent watchdog which keeps an eye on the cost and the burden caused by regulation - which other advisory bodies also look at partly, such as the Council of State - is of course essential to guarantee the monitoring policy on volume and costs. Nevertheless, the government and Parliament are free to depart from the advice given by Actal. It is also worth noting that the history of the burden control policy had an ad hoc character until at least 2011. The Netherlands does not have a strictly permanent policy on the volume or monitoring of regulation. And the assessment and weighing of the coordination of regulation, their burden and effect is in fact carried out only once: when the regulation concerned is in the ground work phase. Looking at the intentions of the recent coalition agreement Building Bridges, of the Rutte cabinet II(2012), it doesn't appear that this tradition will be coming to an end. The agreement contains only a limited policy base with regard to the volume of regulation: 'Do not give in to the reflex to react to every incident with new legislation'. The past has shown that it is extremely difficult to resist this reflex. It would perhaps be just as effective to design a permanent system where regulatory acts that are no longer necessary, or are dysfunctional, can be done away with.

Actal is illustrative of a process that is occurring in many other countries. (Semi) Independent watchdogs are a much sought after means to institutionally embed policies that provide for the testing and assessment of proposed regulation. For example, the European Commission has a semi-independent Impact Assessment Board ${ }^{37}$ and Germany

\footnotetext{
${ }^{35}$ Decree dated 16 June 2011, no. 11.001442, establishing Actal, advisory board for assessing regulatory burden (Instellingsbesluit Actal 2011), Government Gazette 2011, No. 12119.

${ }^{36}$ Regulatory burden is a polyvalent concept. It can exist in absolute terms if the (too high) number of regulations is included (so in numbers), but it can also exist in a subjective sense as the burden of (too many) restrictions as a result of regulations. Regulatory burden is difficult to measure as such. A.J. van Gestel \& M.L.M. Hertogh, 'Wat is regeldruk? Een verkennende internationale literatuurstudie' (Wolf Legal Publishers, Nijmegen 2006) 59 et seq.

${ }^{37}<$ http://ec.europa.eu/governance/impact/iab/iab_en.htm> accessed 16 January 2013).
} 
has a Standard Monitoring Council. ${ }^{38}$ The position of such bodies is of course always a tricky issue. Since these authorities usually have to do their work during the process of the preparation of the regulatory measure, it is not always a good idea to make them too independent or permit them to issue binding advice. Policy formulation and the political responsibilities and choices connected to this could otherwise get in each other's way too often. Semi-independent advisors are quite sought after nowadays in different jurisdictions in Europe. Which is why we are seeing them more and more often.

\section{Simplification of regulation, ceilings, consolidation and other mechanisms}

Policies to control the volume of regulation and - as a result - the burden they entail, as we have seen in recent years in the Netherlands and other EU countries, also at EU level itself, have made remarkable advances. Protocoling the preparation of regulatory measures (attention for the possible consequences of regulation and impact assessment) and institutional arrangements (obligatory impact assessment, watchdogs etc.) seem to be the standard recipes here to prevent the disproportionate or undesirable effects of regulation or at least to control them. Various countries and the EU have, however, also developed methods to permanently keep the volume of regulation under control. The production of regulation from developed countries, as I already showed, has the tendency to expand automatically so that the result of (large) deregulation operations is cancelled after a while. ${ }^{39}$ One of the ways to prevent this is to carry out permanent volume monitoring or permanent simplification programmes. This can be in the form of a regulation monitor, where a check is kept on the production of regulation, or mechanisms that contribute towards simplification - and thus often a reduction - in regulation. I already mentioned the example of Law Commissions, but also by using a form of codification (repealing multiple regulatory acts in a certain area and replacing them by one integrated regulation), harmonization or consolidation (publishing various amending acts as a continuous text) regulatory acts can be simplified, therefore resulting in less burden. These are important instruments in the regulation policy of the European Union (Better regulation). ${ }^{40}$ Though at first glance it does not appear to be self-evident that by reducing the number of pages of regulatory acts, the burden resulting from them is also reduced (the content after codification or consolidation of regulatory acts usually remains the same), this correlation does actually exist in the European Union. Because of the high cost involved in the compulsory translation of all EU legislation texts in the official languages of the Union, it certainly pays to reduce the number of pages to be translated. ${ }^{41}$

\footnotetext{
$38<$ http://www.normenkontrollrat.bund.de/Webs/NKR/DE/Homepage/home.html> accessed 16 January 2013).

${ }^{39}$ See W. Voermans, 'The Sisyphus paradox of cutting red tape and managing public risk' (2008) 4(3) Utrecht Law Review 128-144.

${ }^{40}<$ http://ec.europa.eu/governance/better_regulation/simplification_en.htm> accessed 15 January 2013)

${ }^{41}$ See W. Voermans, C. Moll, N. Florijn en P. van Lochem, 'Codification and Consolidation in the European Union: A Means to Untie Red Tape’ (2008) 29(2) Statute Law Review 65-81.
} 
Another instrument that is applied to control the volume of regulation is the so-called 'ceiling' method: setting a maximum for the costs induced by regulation that an agency or ministerial department is allowed to produce. In itself, it is a rather silly system because it number of regulatory acts says nothing directly about the burden caused by these regulatory acts, can be easily manipulated and relies too much on automatisms. This method was therefore never implemented in the Netherlands, though between 2005 and 2007 we did have a version of it when agreements were made concerning the maximum administrative burden ceiling for each department. Ministries were then forced like a kind of 'Zalm standard" tion programmes or other forms of compensation in the event they exceeded the ceiling.

Likewise the current British government has decided in its coalition agreement to put a cap on the burden of regulatory acts. Since 2010 the United Kingdom has a so-called 'one-in, one-out rule' which entails for every new regulation imposing a new net cost (in), an equivalent value of regulatory burden has to be repealed to compensate (out). The thought behind this, is that it does not merely contribute to a reduction in the burden, but it also contributes towards a culture shift in the area of regulation. ${ }^{43}$ This is something the Rutte II cabinet has also called attention to in its coalition agreement.

The case study of the development of regulatory policies in the Netherlands provide a clear example of the path dependency that the original idea that regulation is a per se impediment of some sort to market development creates. One can see this quite clearly by asking the question: why isn't there a policy that analyses or operationalizes the idea on how regulation can help or foster market growth. Clearly regulation does that too. Contract law, property law, law that creates and enables the sale of licences and rights creates market value and by this economic growth. But this element is not very prominent in debates on regulatory policies. And no methods, processes nor tools exist to improve the market performance or increase the (potential) value of regulation for markets in any liberal democracy I know of. The second point the analysis of the history of regulatory policy in the Netherlands demonstrate is that the causal relation of the underlying working hypothesis - if regulation is reduced (or the burden thereof) markets growth is not really tested nor really proven. The Dutch case study shows that most of the evidence provided is at best circumstantial.

\section{METHODS TO MEASURE THE PERFORMANCE OF REGULATION}

Current regulation policies of many OECD countries are founded on the same basic hypothesis as the one we discussed in the USA and the Netherlands. It departs from the notion that the more we know about the performance of regulation - in terms of estimat-

\footnotetext{
${ }^{42}$ This was a Dutch norm on budget deficits in the 1997-2007 decade requiring that deficits on departmental budgets should be borne by the department itself and compensated within the departmental budget.

${ }^{43}<$ http://www.defra.gov.uk/corporate/about/how/regulation/> accessed 8 January 2013.
} 
ed impact - the better we will be able to make more responsible choices and as a result be able to establish better and more effective regulation. Although the causal connections on which this hypothesis is based - as we have seen - have not yet been proven, it has led to a process in the past 10 years in OECD countries (like the Netherlands) where much effort has been put into searching for objective and reliable indicators that can be used to measure possible performance (in terms of estimated impact). One of the methods is the Standard Cost Model (SKM) which was actually developed in the Netherlands. The SKM is an instrument (calculation method) to identify the administrative burden involved in a regulation. The method also makes it possible to assess what the effect is of a reduction in the administrative burden of existing and proposed regulation. The SKM calculates the administrative burden using the following formula:

- Total administrative burden of a regulation $=$ the sum of the costs of every duty of disclosure

- Cost of every duty of disclosure = the sum of the costs of every action

- Cost of every action $=\mathbf{P} * \mathbf{Q}$

$\mathrm{P}$ is defined as the cost of an administrative act and $\mathrm{Q}$ as the number of times that this administrative act has to be or is performed.

The SKM has become a success story. It is used as a standard in many EU countries ${ }^{44}$ and is also used for the impact assessment that is carried out today for almost every substantial proposal for an EU directive or EU regulation.

It is very tempting to take a look at all sorts of assessment methods. They exist in fields such as environmental effects, social and economic effects, equal treatment for men and women, human rights, sustainability etc. However, I will resist the urge, as it is more interesting to take the time to consider two other developments. Firstly, the increasing need to quantify the effects that proposed regulation can lead to, and secondly the attempts that are made to objectify these kind of estimates by standardizing them or have them meet scientific criterion.

This first development was already discussed in previous paragraphs. When regulatory acts are prepared, there is an increasing need to find out more about the possible effects. Radaelli and Fritsch ${ }^{45}$ show in a recent contribution that countries are increasingly searching for indicators that give a reliable picture of the possible effects of a regula-

\footnotetext{
${ }^{44}$ For example in Germany. There is even a network of SKM users. For the countries who use the method, see the summary that the network produced on <http://www.administrativeburdens.com/> accessed 18 January 2013.

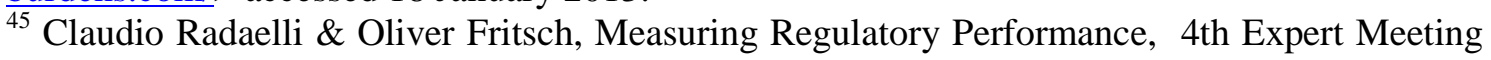
of the OECD Regulatory Policy Committee on 'Communicating and Measuring Progress in Regulatory Reform: Developing a Framework for Measuring Regulatory Performance in OECD Countries', 11-12 April 2012, Madrid, Spain 2012.
} 
tion. $^{46}$ They divide these into Input indicators (impact on budgets or budgets for regulation), staffing capacity, training, etc. i.e. what does it cost to produce the regulation), Process (of system-level) indicators (length and planning of the regulation process, performance of the regulation process ${ }^{47}$, planning consultation, monitoring the production of regulation, when to carry out which checks, etc.), Output indicators ('forward planning' - in countries where a budget for regulation exists, establishment of criteria for impact assessment in relation to the objectives of the regulation, the method of establishing models for macro and micro economic calculation of the effects, establishment of questions for consultation, etc. - in short, the incorporation of the measurement instrument for impact assessment) Intermediate outcome indicators (perception surveys ${ }^{48}$ - among 'regulators' and citizens and businesses) and final outcome indicators (estimate of the administrative burden, economic and financial effects, cost and effort for enforcement, etc. - in short the estimations themselves). The picture that arises here is of increasingly detailed 'knowledge' of the effects that regulation brings by measuring it better. As a result, the quality of measurement methods is improved.

The second development is directly linked to this: the need for the objectification and standardization of assessment results and measurement methods. If data from research is to be convincing, it will have to have been made objective (i.e. not the result of the opinion or belief of an individual). In a politically sensitive environment, it is also important that the criteria that are applied for any measurement are standardized. Because SKM is adhered to as a factual (de facto) standard, the measurement instrument for administrative burden can also be used in a political and administrative context. It provides 'facts' on the basis of which - in a public discussion - a political and administrative assessment can be made. For this reason, Radaelli and Francesco already proposed in 2007 the calculation of economic consequences to establish transnational standard 'final economic indicators' derived from indicators and measurement standards that have been developed and tested globally, because this can reinforce the 'evidence base' for a regulation. ${ }^{49}$ One of the last developments in that field is that of the risk analysis for proposed regulation, a development that doesn't seem to have taken off in the Netherlands. An attempt is made for many regulatory acts to make risks manageable in the

46 See the OECD initiative Indicators of regulatory management <http://www.oecd.org/gov/regulatorypolicy/-ria.htm> last accessed 18 January 2013).

${ }^{47}$ See in this regard the report H.M.Th.D. ten Napel, W. Voermans, M. Diamant M.M. Groothuis,B. Steunenberg, R. Passchier, S. Pack, Legislative Processes in Transition (WODC, The Hague/Leiden 2012).

${ }^{48}$ Perception surveys are starting to play a role in the Netherlands, for example within the framework of perceived regulatory burden. It is one thing to measure whether - in an absolute sense - regulatory burden exists, increases or decreases as a result of new regulations. But that is not to say that this matches the way in which the increase or decrease of the burden is perceived by those who have to work with the regulations. See for example C.H. Kamphuis, Ervaring van regeldruk binnen de Enschedese uitvoeringsinstantie van de Wet werk en bijstand (Experiences with Regulatory pressure in the Enschede welfare agency) (Twente University, Enschede 2010).

${ }^{49}$ C.M. Radaelli, F. De Francesco, Regulatory Quality in Europe; Concepts, Measures and Policy Processes (Manchester University Press, Manchester 2007). 
areas of income, social relationships, incidents, etc. Careful analyses, on the basis of measurement methods that make good predictions, can be used to determine how great the risks are and on that basis an assessment can be made of which risks can be made manageable in what way and at what cost. In other countries risk analysis (estimated as objectively as possible $)^{50}$ is slowly beginning to play a role in the preparation of regulatory acts. ${ }^{51}$ The wheel does not have to be continually re-invented here; insurance companies throughout the world use measurement methods and probability calculations that produce reliable estimates on the nature and frequency of certain risks. A recent development since 2005 that seems to be persisting is that when calculating the effect of regulation, not only is the burden of the regulation considered but also an attempt is made to calculate as accurately as possible what the yield or advantage of a regulatory measure is and in this way to arrive at an accurate cost-benefit analysis. ${ }^{52}$

A noteworthy parallel development to quantification, objectification and standardization is the development of standardized manuals, practical manuals and instrument panels (regulatory toolkits) that are shooting up like mushrooms everywhere. These manuals do not only attempt to make the number of measurement dimensions of regulation manageable and to make them operational for the organisations that have to work with them, they are also an institutional memory and are used as laboratories to assist in making protocols and refining impact assessments.

What is also interesting, is that in the developments described above the investments that various countries and the EU have made in recent years to improve our 'knowledge' about legislation were made during the preparation process of regulation in particular. Ex post evaluation of regulation, to see if the objectives set have been achieved and methods to better discover if regulation work as intended and the cost of these, would seem to have played a less important role. That is not to say that the science of ex post evaluation has stood still completely, but relatively speaking less policy investments have been made which is strange when you consider that the actual effects of regulation can only be established when one has a good insight into the complete cycle including preparation, establishment, implementation, evaluation and possible amendment.

\section{E. IMPLICATIONS OF THE QUANTIFICATION TREND WHEN DEALING WITH REGULATION}

\footnotetext{
${ }^{50}$ If you want to do it objectively, a quantative approach can also be used here. Quantitative risk assessment requires calculations of two components of risk (R):, the magnitude of the potential loss (L), and the probability (p) that the loss will occur.

${ }^{51}$ See for example J. Black, 'The Role of Risk in Regulatory Processes', in: Baldwin, Cave and Lodge (2010) chapter 14.

${ }^{52}$ See W. Voermans, 'The Revenue of Regulation' (2012) 32(8) Bubeyon Magazine 21-23.
} 
This contribution tried to outline and analyse the quantification trend in regulation. An interesting effect of this quantification trend is that jurisdictions - perhaps because of regulatory competition - are adopting each other's regulatory appraisal practices at an extraordinary pace, most of the time to enable policy makers to gather more and better information about the possible effects of regulation. In this process - particularly in OECD countries - they don't just copy each other's methods but to a certain extent also each other's institutional arrangements. This is remarkable because we do not yet know what the eventual specific results of these quantified regulatory appraisal methodologies will be in the long run and in different settings.

One effect we can be sure about at this moment is that quantification regulation in any case can enable regulators to take decisions on the basis of better information and that a better information base will also enable regulators to weigh up the content of alternative solutions. A better insight into the possible consequences and effects of a regulatory solution can also be helpful for the regulatory process itself; a firm information base makes results in an informed and structured debate and by this can make the decision process more 'inclusive'. On the other hand, there are a few question marks. Framing the debate on regulation in mere quantative terms may over-technify the regulatory process. If regulatory proposals have a very technical evidence base (due to the complex appraisal methods used), it may become very hard for citizens, businesses and organizations to provide evidence to the contrary. Certainly in the case where, similar to in the Netherlands, the estimates and facts derived from these appraisal methods cannot be independently challenged, because they are part of an integrated assessment, of which only the final outcome is presented in explanatory documents. Next to that a lot of current quantitative appraisal approaches quite often have a sort blind spot. They tend to single out some effects and do not always weigh these in their (total) context. ${ }^{53}$

For example, the actual disadvantages and advantages of a regulatory alternative in terms of effects can often only be estimated against the background of a sound risk analysis: what effects, in which risk scenario, at what cost? Risk analysis is as of yet not firmly footed in regulatory policies, and most of the time conducted on the basis of political intuition.

Another risk linked to quantification of regulation is that estimates and facts that result from appraisals are not always indisputable even though they come with the aura of objectivity. Facts and estimates can - even invisibly - be manipulated. As Albert Einstein famously noted: "If the facts don't fit the theory, change the facts." When regulatory acts are being prepared, a risk exists that estimates are presented or set out in a certain way so that they support the objective of the regulation which had already been fixed. If a certain administrative or political commitment for a solution or a line of policy already exists, it is notoriously difficult to retrace one's footsteps or to seriously consider other alternatives. This leads to political and administrative losses and costs that are not easy to convey or include in the profit and loss account of the regulatory pro-

\footnotetext{
${ }^{53} \mathrm{~W}$. Voermans (2012), 21-23.
} 
posal at hand. In addition, the over-technification of the preparation of regulation does not contribute to dampening the aspirations of regulators and their self-image. We referred to one of the causes of the increasing number of regulation as the 'mechanism' or 'cockpit syndrome', this being the exaggerated expectations we hold when it comes to the power of regulation to solve problems in our type of society. Here the quantification trend indeed feeds the idea that there are working and reliable switches and buttons on the public service ship which make it possible to steer society. But - as we well know - this is not the case in reality. As much as we would like it to be, regulation is not the software of society.

There is still another element to be considered. Regulation in a liberal democracy serves more goals than mere market control or performance. A big focus on market effects and costs of regulation can result in too little attention for the public interest-element in regulation. Regulation also serves to correct market failure, to protect vulnerable (minority) interests, to ward of risks, etc. There are important regulatory rationales beyond the economic. ${ }^{54}$ Over-emphasizing the economic aspects of regulation may lead to a situation in which - like Ackerman and Heinzerling have put $i^{55}$ - we know the price of everything and the value of nothing.

\footnotetext{
${ }^{54}$ M. Feintuck, Regulatory rationales beyond the economic, Baldwin, Cave and Lodge 2010, 39-63.

${ }^{55}$ F. Ackerman \& L. Heinzerling, Priceless. (the New Press, New York 2004).
} 